\title{
Assessment of cover to reinforcement in slabs using different spacer and tying distances
}

\section{Análise da espessura do cobrimento de armadura em lajes com diferentes distanciamentos entre espaçadores e pontos de amarração}
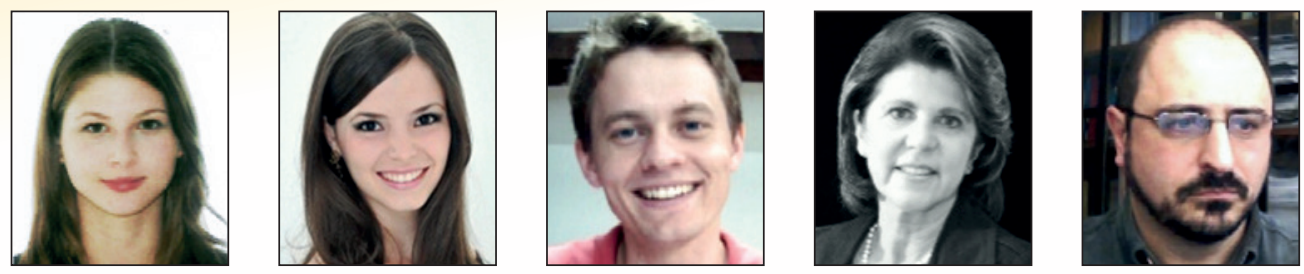

A. P. MARAN a anapaulamaran@gmail.com

M. F. F. MENNA BARRETO ${ }^{\circ}$ mfmennabarreto@gmail.com

A. B. ROHDEN abrcivil@gmail.com

D. C. C. DAL MOLIN dmolin@ufrgs.br

J. R. MASUERO a

joão.masuero@ufrgs.br

\begin{abstract}
Given that the durability of structures is directly related to the thickness of the cover to reinforcement, it is essential to ensure minimum cover is achieved when building a structure. However, studies show that this is not always the case. One of the reasons for the this problem is the lack of indication, in structural projects, of the positioning of spacers. This situation is compounded by the lack of standards and regulations on the use of spacers (i.e. minimum quantities and required layout). This study assesses three different spacer distances and two different tying distances in order to examine the influence of these factors in the cover to reinforcement. To achieve so, three slabs were prepared in situ using different arrangements. After demoulding, cover thickness was determined using a digital covermeter. It was observed that the factors investigated have a significant influence in the final cover.
\end{abstract}

Keywords: ccover, spacer, tying, reinforced concrete.

\section{Resumo}

Uma vez que a durabilidade das estruturas está diretamente relacionada à espessura de cobrimento da armadura, é imprescindível que o cobrimento mínimo normatizado seja garantido durante a execução da estrutura. Entretanto, pesquisas comprovam que o cobrimento não está sendo alcançado. Dentre as razões para isto, aponta-se a falta de indicações nos projetos estruturais do posicionamento dos espaçadores. Esta situação se agrava pela falta de normatização e regulamentação do uso (quantidades mínimas e disposição necessárias) dos mesmos. Neste sentido, esta pesquisa tem como objetivo analisar três diferentes distâncias entre espaçadores e dois distanciamentos entre pontos de amarração a fim de analisar a influência destes fatores no cobrimento das armaduras. Para isto, foram concretadas lajes in loco com diferentes combinações. Após a desfôrma, os cobrimentos foram medidos com auxílio de um pacômetro digital. Constatou-se que os fatores estudados influenciam significativamente no cobrimento final.

Palavras-chave: cobrimento, espaçador, amarração, concreto armado.

Universidade Federal do Rio Grande do Sul, Departamento de Engenharia Civil, Escola de Engenharia, Núcleo Orientado para Inovação da Edificação, Porto Alegre, RS, Brasil. 


\section{Introduction}

Reinforced concrete has been undergoing ongoing improvements since the late $19^{\text {th }}$ century and it is the most widely used construction material worldwide because of its cost-effectiveness, durability and multiple applications [1]. However, in the last decades, degradation phenomena in concrete structures that are only a few years old have become increasingly common [2]. This early decay may be a result of project design failures, project execution or the use of unsuitable materials in aggressive environments [1]

The problems associated with the durability of reinforced concrete structures are observed mainly in $\mathrm{CO}_{2}$ - and/or chloride-rich environments. Aggressive agents in the environment penetrate the concrete and may induce early decay, affect service performance and, in serious cases, cause structural failure [3]

Thus, the durability of a structural system consists of preserving the safety, stability and service usefulness of a given structure throughout its service life while considering the environmental conditions specified in the project [4]. This requirement is highly dependent on the characteristics of the concrete cover to reinforcement and its thickness [2]

While the porosity of concrete is a key element affecting the protection of the reinforcement, so is the cover thickness. The concrete layer, which is the distance between the nearest face of the concrete and the steel reinforcement, provides physical protection in the form of a barrier, as well as chemical protection in the form of a passivation layer created by the high alkalinity and the insulating effect of the concrete [5].

Failure to achieve the specified concrete cover is probably the greatest single factor influencing the premature corrosion of reinforcement [6], which is, in turn, the main type of deterioration observed in reinforced concrete structures [7] and the most costly as far as maintenance if concerned [1]. However, engineers do not usually perceive the need for a proper cover as a priority and therefore do not give due consideration to ensuring it is obtained [7] Still, one of the major problems associated with reinforced concrete structures is the failure to position the reinforcement with the correct cover of concrete, thus impairing the mechanical properties and the durability of the structure [8].

As far as the structural performance of slabs and beams is concerned, the global safety factor increases as the cover thickness decreases [9]. This is not the case, however, with durability, as a thicker cover improves the protection to the reinforcement [10]. Therefore, these competing factors must be balanced.

As a result, the design and execution of reinforced concrete structures must take into account the nominal cover prescribed by the applicable standard [4], which specifies a 10-mm tolerance for the minimum cover for each environmental aggression class. However, where a quality assurance system and strict tolerance limits during execution are in place, it is possible to adopt a value of $5 \mathrm{~mm}$.

Although the Brazilian standard states that the quality control must be clearly defined in the design, it does not indicate the parameters the project designer can use to adopt a given tolerance value. The designer is free to define and specify the tolerance in the design. Thus, any execution is free to claim it adopts strict controls and this often results in 5-mm tolerance values being used. However, studies indicate that a tolerance of $5 \mathrm{~mm}$ in the nominal cover does not reflect the cover distribution found in practice [7].

To make matters worse, the standard addressing the execution of reinforced concrete structures lists a single requirement to ensure the specified cover is achieved: the use of spacers [11]. However, there is no reference to their distribution and layout. The method used is part of
Figure 1 - Tying points $15 \mathrm{~cm}$ apart with spacers $60 \mathrm{~cm}$ apart

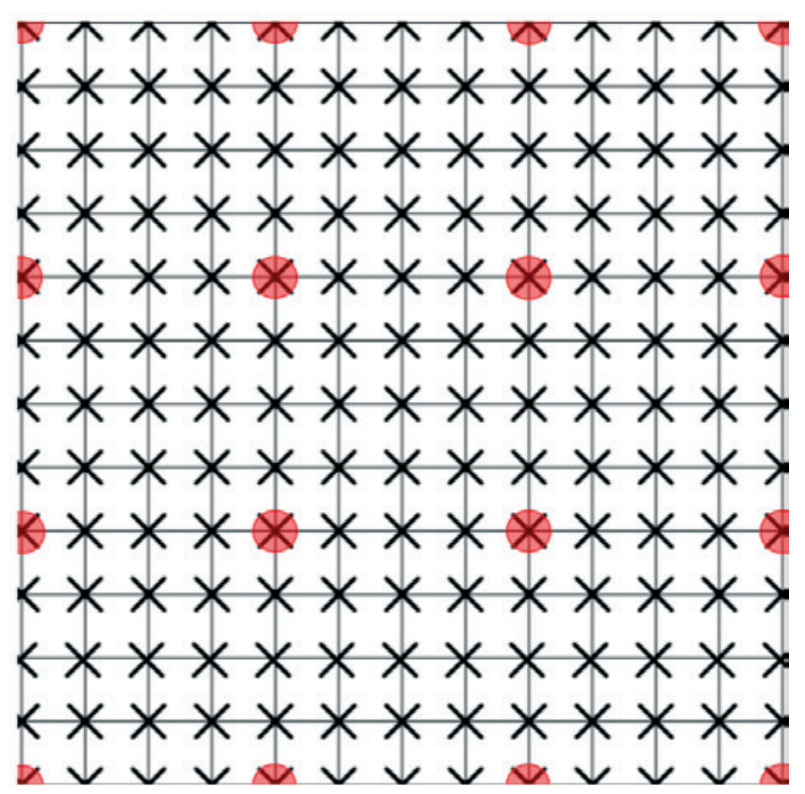

Figure 2 - Tying points $30 \mathrm{~cm}$ apart with spacers $60 \mathrm{~cm}$ apart

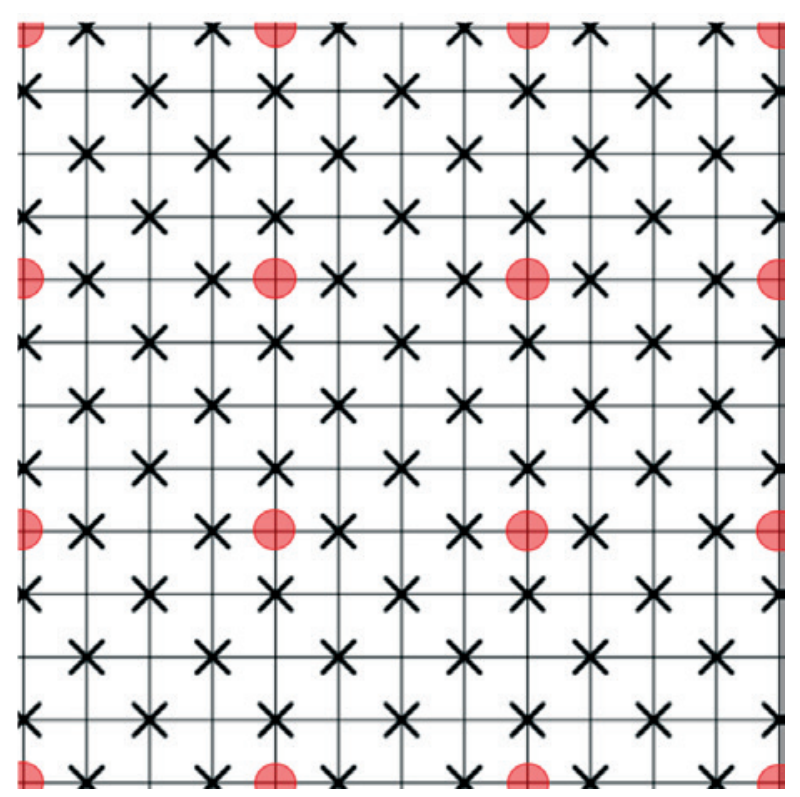


Figure 3 - Tying points $15 \mathrm{~cm}$ apart with spacers $45 \mathrm{~cm}$ apart

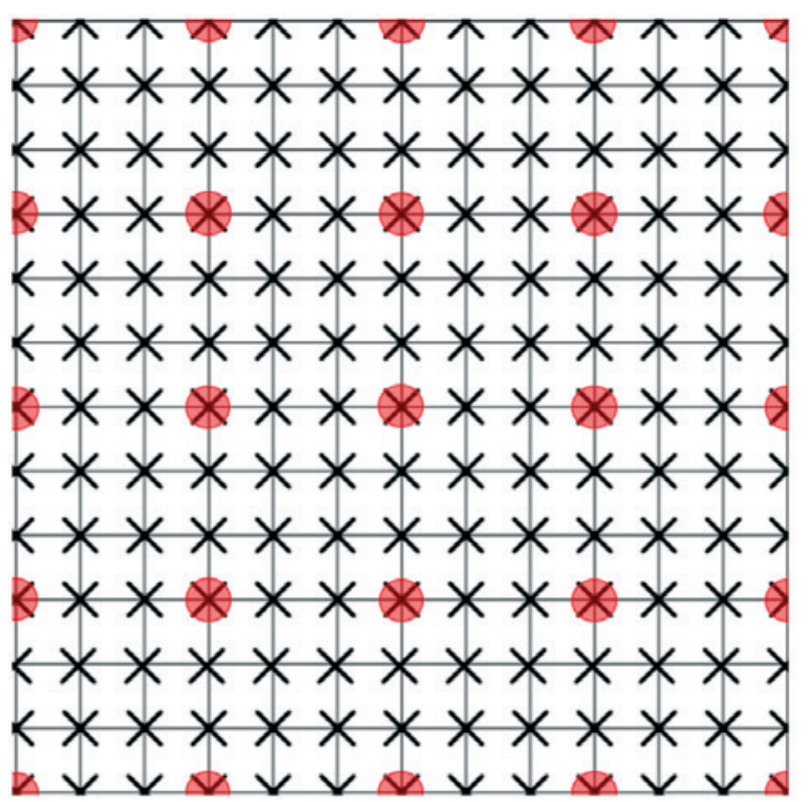

the execution. This is different from European standards, which specify the distribution of spacers according to the structural element and define minimum and maximum distances between them [12][13][14].

However, several international studies have shown that the actual cover achieved does not usually meet design specifications [6]. Research indicates that $90 \%$ of corrosion cases are a result of poor placement of the reinforcement [15]. A study in the city of Porto Alegre, Brazil, showed that $44 \%$ of the cover thickness values before concrete placement were below the value specified in the project. After placement, this increased to $50 \%$ [16].

The aim of this study is thus to analyze factors that may influence the achievement of cover according to standards by controlling the execution of reinforced concrete slabs. To do so, we controlled the tying of the steel reinforcement, the positioning of plastic spacers and the concrete placement in the slabs in order to analyze their effect on the resulting final cover.

\section{Materials and experimental program}

\subsection{Choice of construction site}

The construction site where this study was carried out belongs to a private company. It is a residential building with several stories, located in the city of Porto Alegre, in Brazil. It is an urban construction and it is classified as Environment Class II (moderate aggression) [4].

\subsection{Choice of slabs}

Studies indicate that the cross section of the reinforcement affects the final cover of the slabs. All things being equal, the thicker a

\section{Figure 4 - Tying points $30 \mathrm{~cm}$ apart with spacers $45 \mathrm{~cm}$ apart}

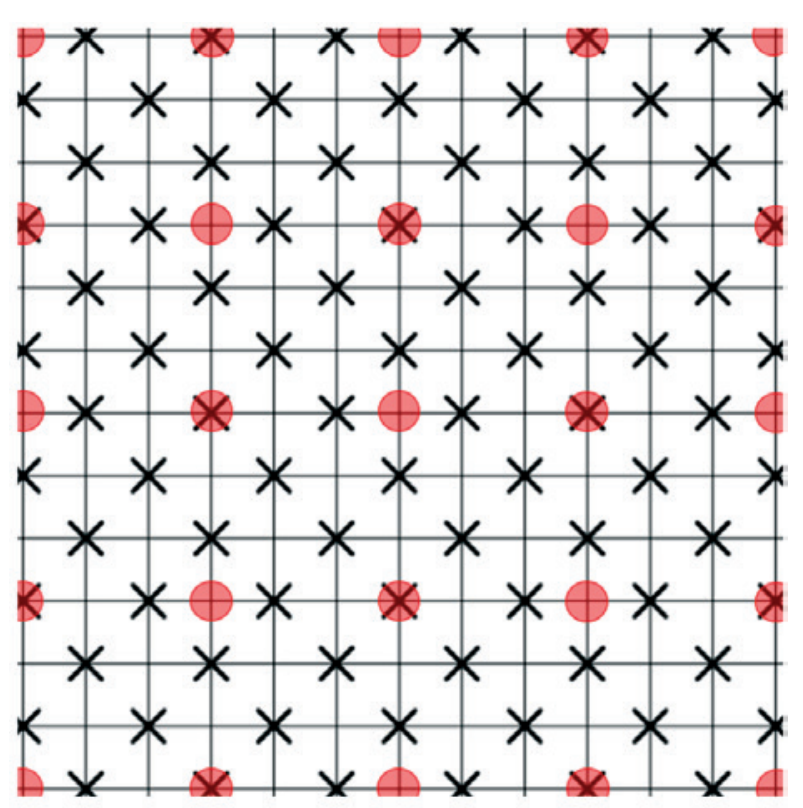

reinforcement, the greater the probability of meeting the minimum cover specified in the project [18]. Thus, $\phi 5,0 \mathrm{~mm}$ reinforcements (the smallest diameter allowed by the standard, with the exception of welded grids) [4] are the most critical. Therefore, an attempt was made to reproduce and assess this critical situation, and the following configuration resulted:

The monitored specimens are solid reinforced concrete slabs, cast in situ, measuring $3.60 \mathrm{~m}$ by $2.60 \mathrm{~m}, 10-\mathrm{cm}$ thick and with a designed cover of $20 \mathrm{~mm}$. The reinforcement consists of CA 60 steel rebars, which measure $5 \mathrm{~mm}$ across and are laid out to form a grid with $15-\mathrm{cm}$ openings. Plastic chairs and size 16 tying wire $(\varnothing 1.65 \mathrm{~mm})$ were used. Concrete placement was performed by a contractor using pumps and hoses. Pumped concrete properties were $\mathrm{f}_{\mathrm{ck}}=25 \mathrm{MPa}$, slump $=12 \pm 2 \mathrm{~cm}$, and coarse aggregate with maximum characteristic size $=25 \mathrm{~mm}$ was used.

Eight equivalent slabs were selected (size, location on the floor, reinforcement ratio, mesh opening, etc.), distributed over two floors. On the first floor, the tying points were placed $15 \mathrm{~cm}$ apart and the spacers were placed at 30,45 and $60 \mathrm{~cm}$ intervals, as shown in Figure 1, Figure 3 and Figure 5. One of the slabs was not controlled, on purpose (none of the factors). The same procedure was followed on the second floor, the only difference being the distance between the tying points, which was $30 \mathrm{~cm}$, as shown in Figure 2, Figure 4 and Figure 6 . In the figures, the $X$ shows the tying point and the red circle is the position of the spacer.

Figure 7, Figure 8 and Figure 9 shows the position of the spacers at 30,45 and $60 \mathrm{~cm}$ intervals.

\subsection{Controllable factors}

The first controllable factor, namely the tying points in the steel 
Figure 5 - Tying points $15 \mathrm{~cm}$ apart with spacers $30 \mathrm{~cm}$ apart

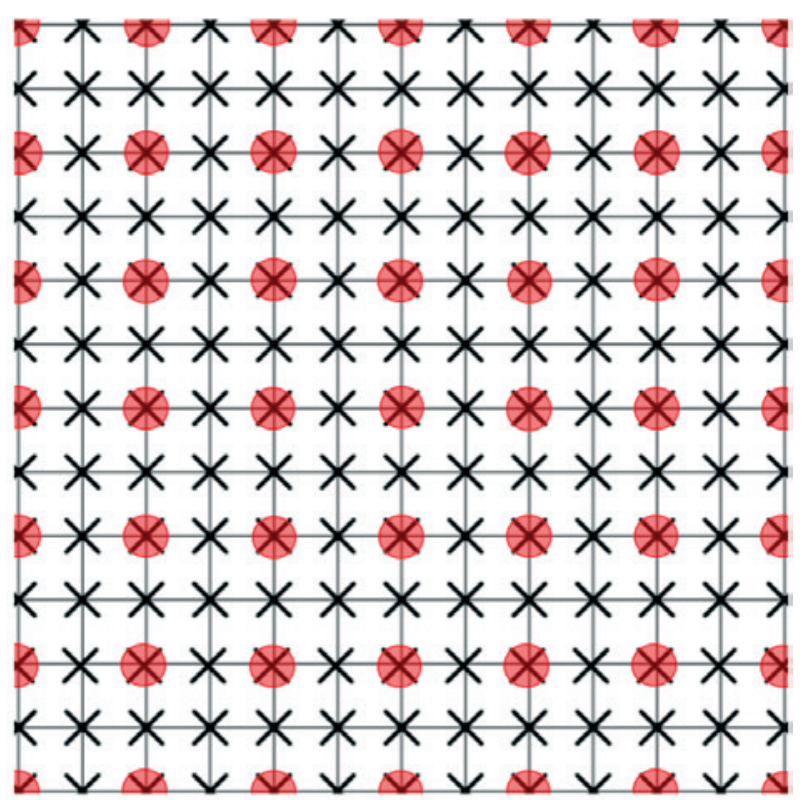

reinforcement, was defined from the specification, which sets a maximum distance of $35 \mathrm{~cm}$ between tying points in slabs [4]. In compliance with this standard, the intersections of the rebars

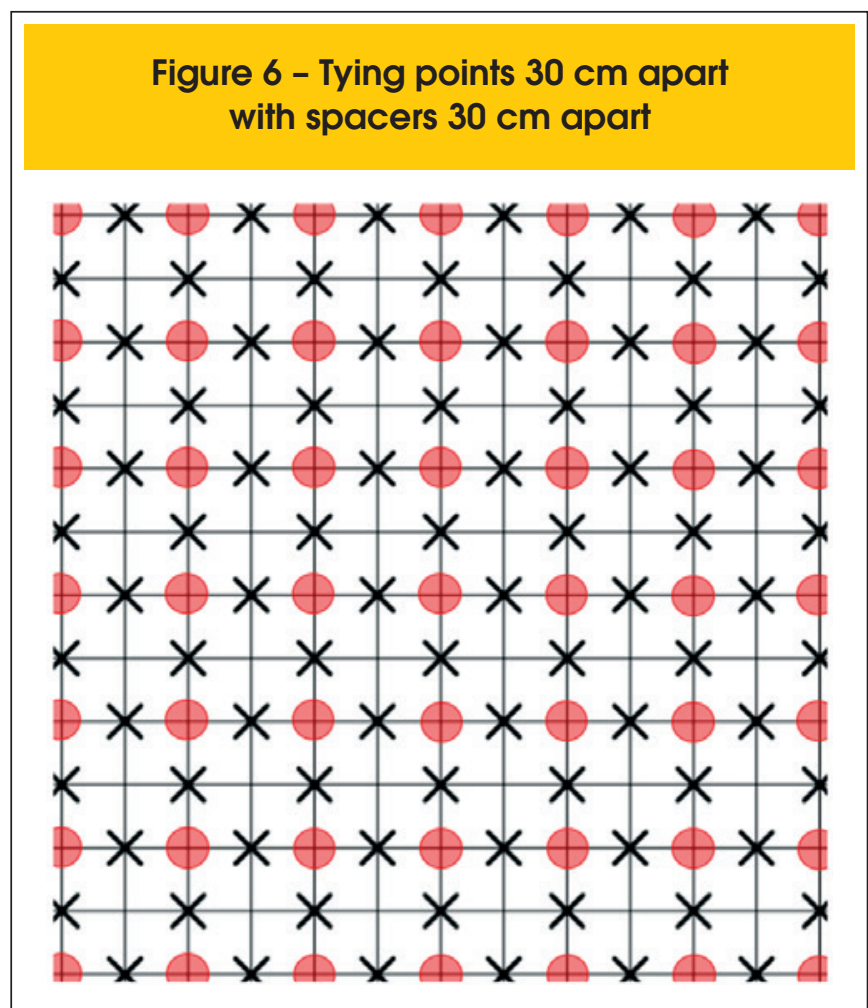

Figure 7 - Layout of spacers placed at $30 \mathrm{~cm}$ intervals in the construction site before concrete placement

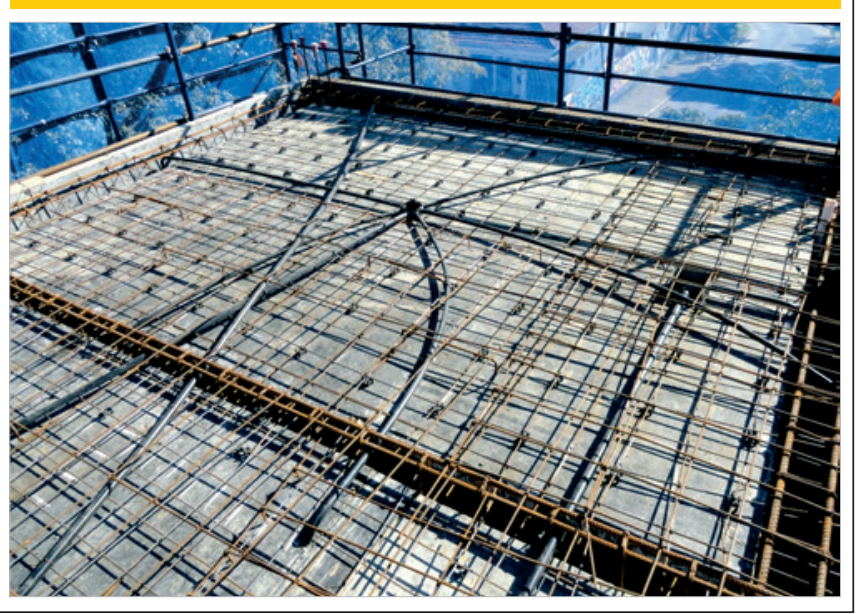

were tied at $15-$ and $30-\mathrm{cm}$ intervals, i.e. the minimum and maximum allowed distance according to the mesh opening.

The second controllable factor was the distance between the spacers. As there is no Brazilian standard addressing this issue, distances of 30,45 and $60 \mathrm{~cm}$ were used, i.e. multiple distances in the mesh openings so that the spacer was placed at the intersection of the steel reinforcement, in compliance with the intervals (minimum and maximum values) specified in European standards [12][13][14].

\subsection{Measurements}

After concrete placement, removal of the shoring and demolding of the slabs, cover thickness was measured. Measurements

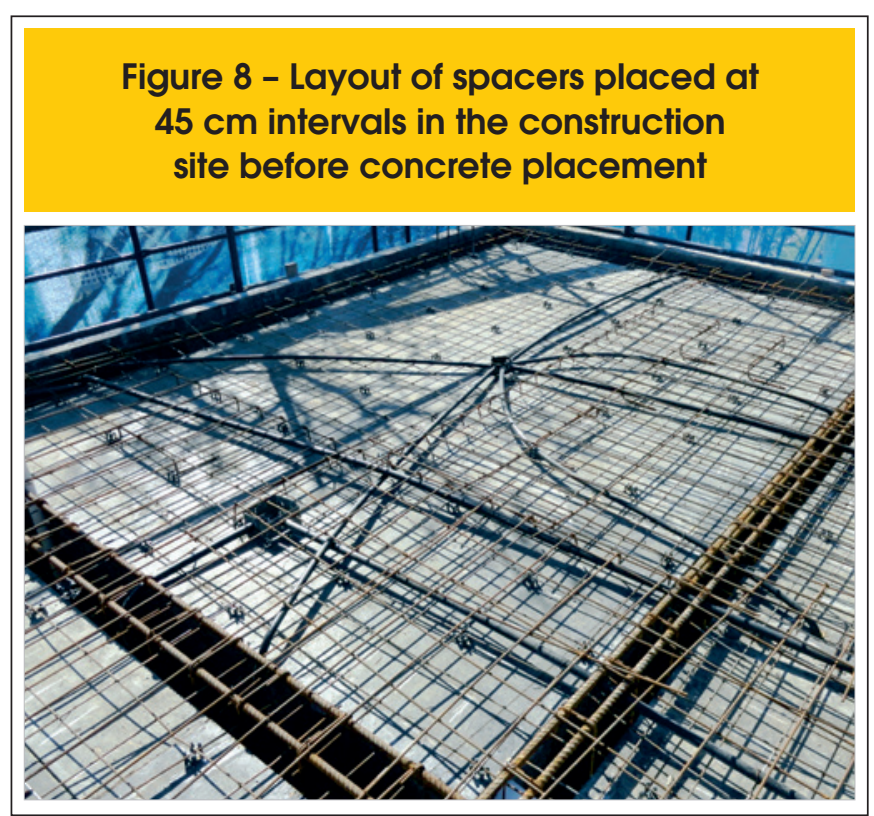




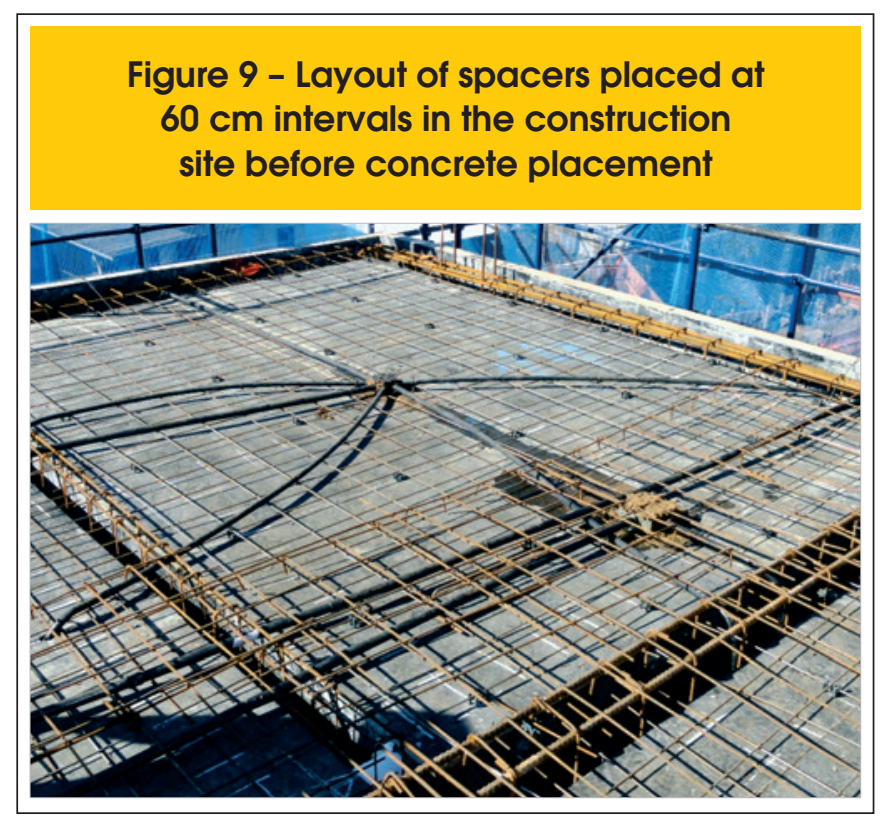

were carried out using an electronic device that can locate the rebars by means of magnetic pulse induction, which generates a magnetic field where a difference in current can be translated as a measurement. The digital pachometer (covermeter) used shows the cover thickness with a precision of $3 \mathrm{~mm}$ in a depth range of $60 \mathrm{~mm}$. However, when adjusted for the actual thickness of the measured reinforcement, the results provided by the device display greater accuracy [17].

Measurements were made on the bottom surface of the slabs, as shown in Figure 10, in order to measure the positive reinforcement. Thirty-four cover thickness measurements were recorded at random in each slab. The two highest and the two lowest values were discarded, resulting in a total of 240 measurements.

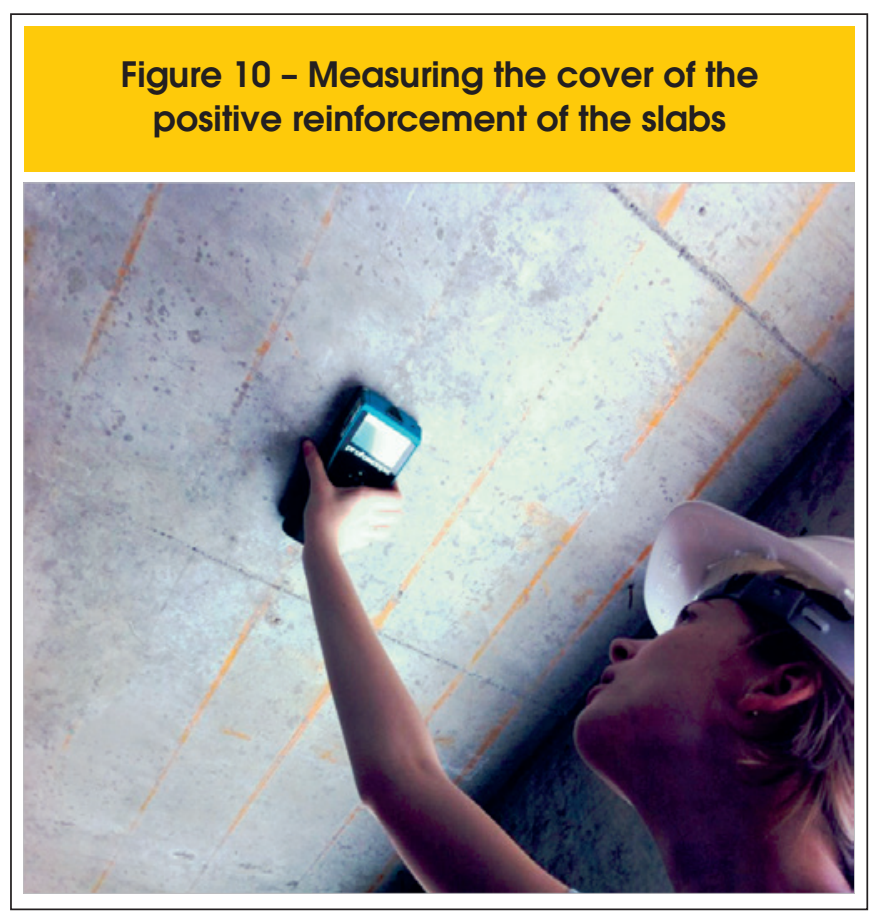

\section{Results and discussion}

The results obtained according to the proposed method are shown in Table 1. The data were checked using Kolmogorev-Smirnov (KS) and Jarque-Bera (J-B) normality tests, which did not indicate any evidence of a non-normal distribution for a significance level of $5 \%$. The results of the normality tests are shown in Table 2.

The residual deviations of the observation were also checked, as Figure 11 shows. It is possible to observe that, even though the dispersion of residual deviation is not constant, no huge variations are observed in the means of the measured cover in relation to

Figure 11 - Residual deviation: (a) cover thickness vs. mean of cover thickness, (b) of cover thickness vs. tying distance, (c) cover thickness vs spacer distance

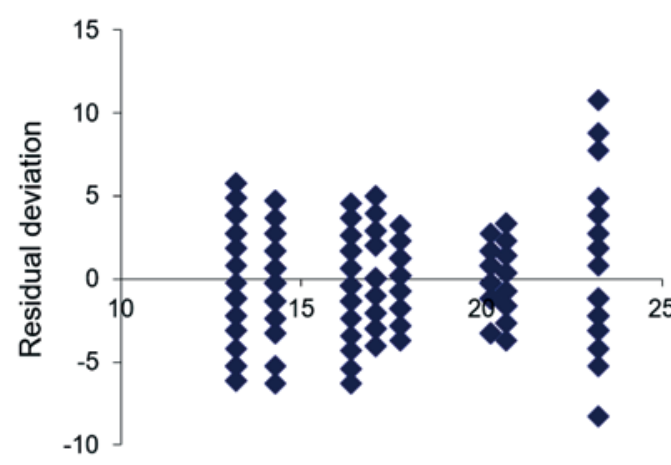

Mean of cover

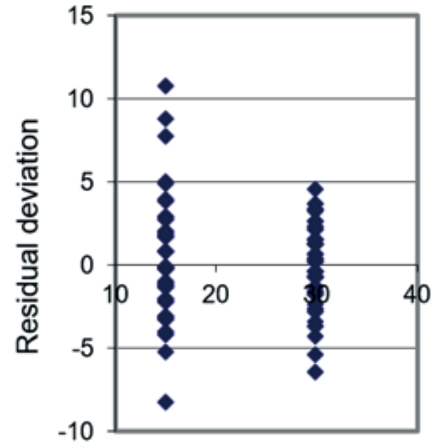

Tying distance

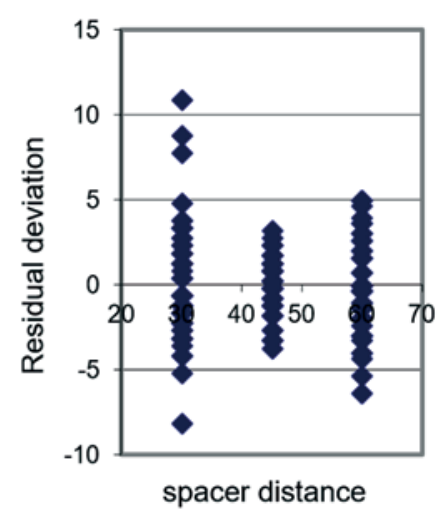

(C) 
the distance between tying points or spacers, which justifies the hypothesis required by the analysis of variance (ANOVA), i.e. that the distribution of the measured values should display the same dispersion but may show differences in mean values.

Thus, in order to check whether the data on controllable factors (spacer distance and tying point distance) indicates an influence on the response variable (cover thickness), an analysis of variance (ANOVA) was carried out with a significance level of $5 \%$, as Table 3 shows.

The results show that the distance between the spacers and the distance between the tying points influence the final cover of the structural element. However, no interaction was observed between these factors and they therefore operate independently.

Figure 12 shows the behavior of the two distances between the tying points assessed.

It can be observed that a distance of $15 \mathrm{~cm}$ between the tying points results in improved performance when compared with a distance of $30 \mathrm{~cm}$. This is due to the fact that the mesh becomes stiffer when all points are tied.

The effect of spacer distances is shown in Figure 13, which dem-

\begin{tabular}{|c|c|c|c|c|c|c|c|c|}
\hline \multicolumn{9}{|c|}{ Table 1 - Results of in situ cover thickness measurements } \\
\hline & \multicolumn{6}{|c|}{ Distance between tying points } & \multirow{2}{*}{\multicolumn{2}{|c|}{ Uncontrolled siab }} \\
\hline & \multicolumn{3}{|c|}{$15 \mathrm{~cm}$} & \multicolumn{3}{|c|}{$30 \mathrm{~cm}$} & & \\
\hline & \multicolumn{3}{|c|}{ Distance between spacers } & \multicolumn{3}{|c|}{ Distance between spacers } & & \\
\hline & $30 \mathrm{~cm}$ & $45 \mathrm{~cm}$ & $60 \mathrm{~cm}$ & $30 \mathrm{~cm}$ & $45 \mathrm{~cm}$ & $60 \mathrm{~cm}$ & L1 & L2 \\
\hline \multirow{30}{*}{8} & 21 & 21 & 15 & 19 & 17 & 20 & 16 & 11 \\
\hline & 18 & 20 & 17 & 17 & 17 & 15 & 18 & 13 \\
\hline & 19 & 22 & 15 & 20 & 18 & 18 & 15 & 14 \\
\hline & 22 & 22 & 17 & 22 & 21 & 21 & 11 & 15 \\
\hline & 26 & 21 & 19 & 19 & 20 & 16 & 7 & 14 \\
\hline & 27 & 20 & 20 & 24 & 16 & 18 & 8 & 14 \\
\hline & 31 & 22 & 17 & 20 & 16 & 15 & 14 & 13 \\
\hline & 34 & 23 & 20 & 22 & 18 & 11 & 17 & 17 \\
\hline & 24 & 17 & 13 & 19 & 18 & 18 & 11 & 17 \\
\hline & 22 & 20 & 22 & 21 & 17 & 18 & 9 & 14 \\
\hline & 25 & 17 & 21 & 18 & 16 & 19 & 10 & 12 \\
\hline & 28 & 19 & 14 & 20 & 14 & 20 & 19 & 15 \\
\hline & 26 & 19 & 22 & 22 & 20 & 16 & 16 & 14 \\
\hline & 20 & 20 & 13 & 24 & 20 & 16 & 12 & 15 \\
\hline & 22 & 20 & 14 & 24 & 19 & 16 & 16 & 15 \\
\hline & 25 & 21 & 16 & 23 & 18 & 16 & 12 & 14 \\
\hline & 19 & 22 & 17 & 21 & 19 & 17 & 13 & 13 \\
\hline & 22 & 21 & 17 & 20 & 16 & 16 & 8 & 19 \\
\hline & 21 & 22 & 17 & 19 & 15 & 17 & 17 & 17 \\
\hline & 21 & 21 & 17 & 24 & 19 & 19 & 18 & 16 \\
\hline & 32 & 21 & 15 & 20 & 18 & 19 & 17 & 13 \\
\hline & 27 & 21 & 17 & 19 & 15 & 10 & 19 & 19 \\
\hline & 25 & 21 & 19 & 20 & 17 & 13 & 17 & 11 \\
\hline & 22 & 20 & 17 & 21 & 18 & 14 & 12 & 16 \\
\hline & 20 & 19 & 14 & 20 & 19 & 15 & 15 & 9 \\
\hline & 21 & 19 & 16 & 22 & 18 & 12 & 10 & 15 \\
\hline & 15 & 19 & 17 & 20 & 19 & 15 & 12 & 16 \\
\hline & 21 & 17 & 19 & 19 & 17 & 17 & 12 & 18 \\
\hline & 20 & 20 & 14 & 18 & 19 & 18 & 7 & 12 \\
\hline & 20 & 20 & 20 & 23 & 19 & 16 & 8 & 8 \\
\hline
\end{tabular}




\begin{tabular}{|c|c|c|c|c|c|c|c|c|}
\hline \multicolumn{9}{|c|}{ Table 2 - Normality test results for measurements } \\
\hline & \multicolumn{6}{|c|}{ Distance between tying points } & \multirow{2}{*}{\multicolumn{2}{|c|}{ Uncontrolled slab }} \\
\hline & \multicolumn{3}{|c|}{$15 \mathrm{~cm}$} & \multicolumn{3}{|c|}{$30 \mathrm{~cm}$} & & \\
\hline & \multicolumn{3}{|c|}{ Spacer distance } & \multicolumn{3}{|c|}{ Spacer distance } & & \\
\hline & $30 \mathrm{~cm}$ & $45 \mathrm{~cm}$ & $60 \mathrm{~cm}$ & $30 \mathrm{~cm}$ & $45 \mathrm{~cm}$ & $60 \mathrm{~cm}$ & Ll & L2 \\
\hline $\begin{array}{l}\text { K-S statistic } \\
\text { (D30) }\end{array}$ & 0.210 & 0.172 & 0.205 & 0.200 & 0.155 & 0.144 & 0.137 & 0.121 \\
\hline P value & $>20 \%$ & $>20 \%$ & $>10 \%$ & $>10 \%$ & $>20 \%$ & $>20 \%$ & $>20 \%$ & $>20 \%$ \\
\hline Normality & YES & YES & YES & YES & YES & YES & YES & YES \\
\hline $\begin{array}{c}\text { J-B statistic } \\
(\mathrm{JB})\end{array}$ & 2.786 & 1.475 & 2.999 & 1.623 & 3.417 & 2.610 & 2.986 & 3.511 \\
\hline P value & $24.8 \%$ & $47.8 \%$ & $22.3 \%$ & $44.4 \%$ & $18.1 \%$ & $27.1 \%$ & $22.5 \%$ & $17.3 \%$ \\
\hline Normality & YES & YES & YES & YES & YES & YES & YES & YES \\
\hline
\end{tabular}

\begin{tabular}{|c|cccccc|}
\hline \multicolumn{2}{|c|}{ Table 3 - Analysis of variance } & (ANOVA) of controllable factors \\
\hline Source & SQ & GDL & MQ & F test & p-value & Sig \\
\hline Spacer distance & 825.64 & 2 & 412.82 & 60.97 & $0.00 \%$ & YES \\
\hline Tying point distance & 160.56 & 1 & 160.56 & 23.71 & $0.00 \%$ & YES \\
Spacer distance $x$ tying point distance & 33.64 & 2 & 16.82 & 2.48 & $8.63 \%$ & NO \\
\hline Error & 1178.13 & 174 & 6.77 & - & - & - \\
\hline
\end{tabular}

onstrates that the cover thickness is inversely proportional to the distance between the spacers. In other words, a distance of 30 $\mathrm{cm}$ showed the best performance of all, while a distance of $45 \mathrm{~cm}$ resulted in better cover when compared with a spacer distance of $60 \mathrm{~cm}$. This behavior is associated with the smaller gap between

\section{Figure 12 - Relationship between the resulting cover and different tying point distances}

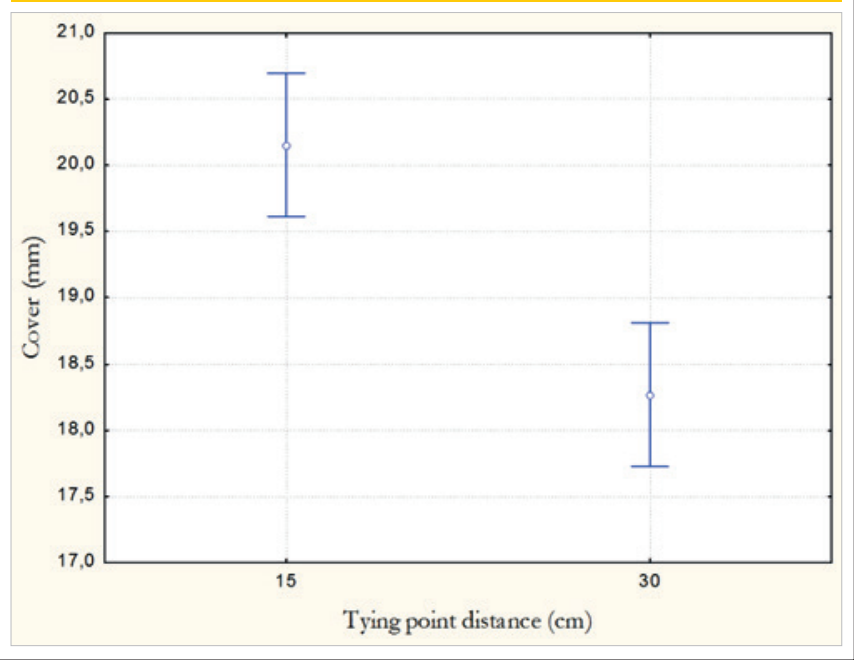

the steel reinforcement. A narrower gap results in less deformation in a given material, in this case, the reinforcement.

By running a new analysis of variance (ANOVA), as shown in Table 4, when all possible combinations (2 distances between tying points and 3 distances between spacers, with a total of

\section{Figure 13 - Relationship between the resulting cover and the distance between spacers}

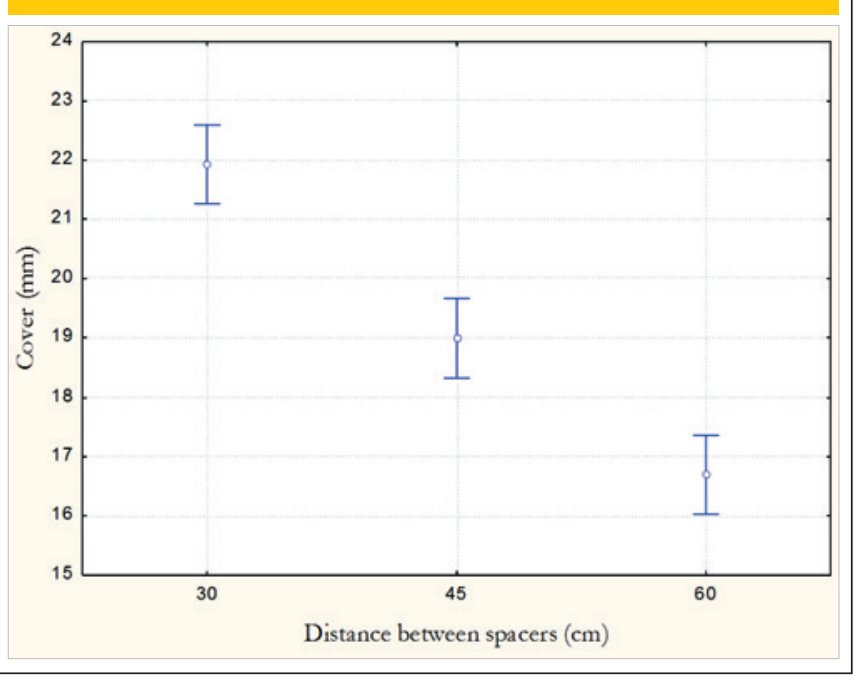




\section{Table 4 - Analysis of variance (ANOVA) of all the possible tying combinations versus cover}

\begin{tabular}{ccccccccc}
\hline Source & SQ & GDL & MQ & F test & P-value & Sig \\
\hline Possible combinations & 1019.84 & 5 & 203.97 & 30.12 & $0.0 \%$ & YES \\
\hline Error & 1178.03 & 174 & 6.77 & - & - & - \\
\hline
\end{tabular}

6 combinations) are compared, a significant difference can be observed between these combinations, which reinforces the findings of Table 3.

Due to the existence of a significant difference between the possible combinations, in order to check for similarities between them, a comparison of the mean values in Figure 14 was made, which adopted as a cutoff limit a value that was three times that of the standard deviation of the mean values of the samples.

$\mathrm{t}$ can be seen that combinations A30E30 (30-cm distance between tying points and $30-\mathrm{cm}$ distance between spacers) and A15E45 (15-cm distance between tying points and $45-\mathrm{cm}$ distance between spacers) show the same behavior, just like combinations A15E60 (15-cm distance between tying points and $60-\mathrm{cm}$ distance between spacers) and A30E60 (30-cm distance between tying points and $60-\mathrm{cm}$ distance between spacers).

Figure 15 further corroborates the results discussed above. It shows that the behavior of controllable factors in inversely proportional to the cover thickness. The absence of interaction between the controllable factors is also illustrated by the fact that when the points of the different distribution levels are connected between the tying points, they do not cross.

In order to check for the efficiency of these combinations in ensuring that the specified cover is achieved, a statistical analysis that took into account a normal distribution was carried out. Given that the Brazilian standard [4] specifies a tolerance of $10 \mathrm{~mm}$ in the execution of the cover, the probability of values falling outside the tolerance range was calculated, i.e. those values below $15 \mathrm{~mm}$ and

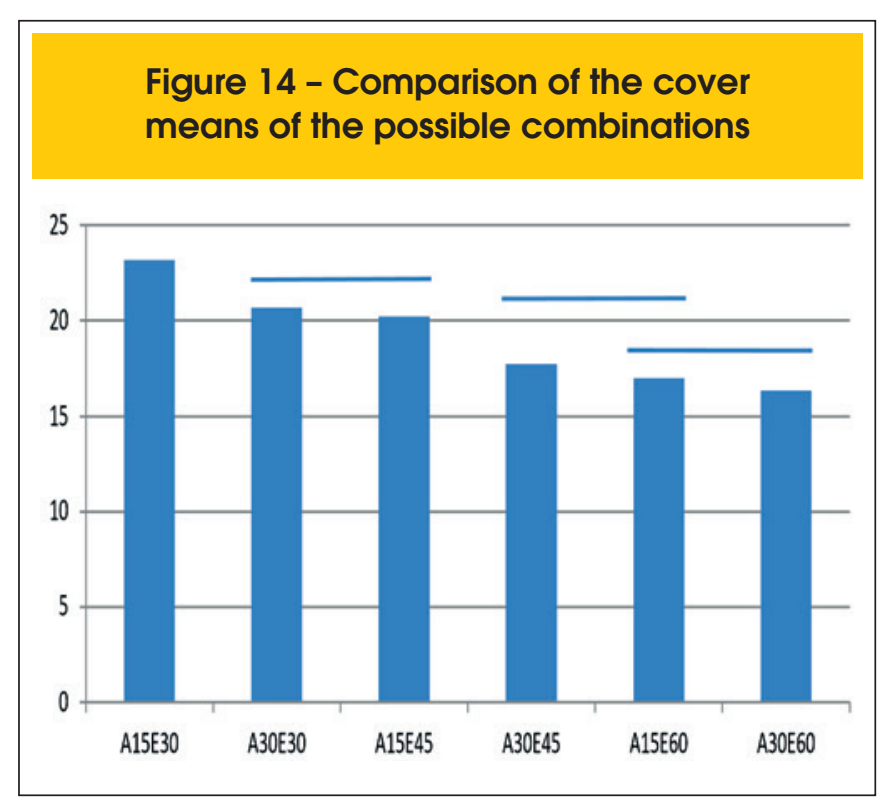

above $35 \mathrm{~mm}$, for all combinations studied and for uncontrolled situations, which are listed in Table 5.

The data show that all combinations, including the uncontrolled slabs, fall within the upper cover thickness threshold. However, for the lower threshold, the combinations with $60-\mathrm{cm}$ spacer distances do not meet the minimum cover thickness values prescribed by the Standard as they have a high probability of resulting in unsatisfactory values. Still, the probability in this case is far lower that what is observed in uncontrolled slabs, which may exhibit non-compliance values in excess of $63 \%$.

\section{Conclusions}

The results obtained and the analyses in this research only apply to the sample investigated, which correspond to a worst case scenario.

Therefore, the results indicate that:

- The distance between the spacers and the distance between the tying points have a significant influence on the resulting cover of the frame in slabs.

\section{Figure 15 - Relationship between the distance between spacers, distance between tying points and cover}

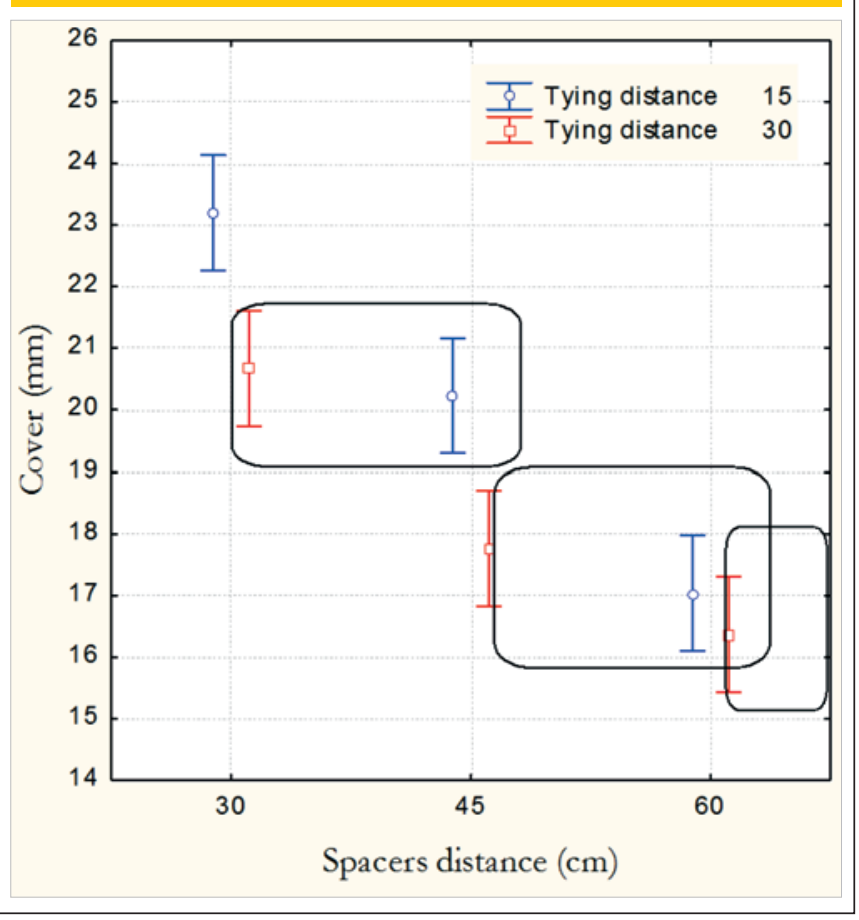




\section{Table 5 - Occurrence of non-compliant values}

\begin{tabular}{|c|c|c|c|c|c|c|c|c|}
\hline \multirow{2}{*}{$\begin{array}{l}\text { Tying distance } \\
\text { Spacer distance }\end{array}$} & \multicolumn{3}{|c|}{$15 \mathrm{~cm}$} & \multicolumn{3}{|c|}{$30 \mathrm{~cm}$} & \multirow{2}{*}{\multicolumn{2}{|c|}{ Uncontrolled slab }} \\
\hline & $30 \mathrm{~cm}$ & $45 \mathrm{~cm}$ & $60 \mathrm{~cm}$ & $30 \mathrm{~cm}$ & $45 \mathrm{~cm}$ & $60 \mathrm{~cm}$ & & \\
\hline Mean & 23.20 & 20.23 & 17.03 & 20.67 & 17.77 & 16.37 & 13.75 & 13.75 \\
\hline SD & 4.29 & 1.52 & 2.54 & 1.95 & 1.68 & 2.61 & 3.27 & 3.27 \\
\hline$\%^{1}<15 \mathrm{~cm}$ & $2.8 \%$ & $0.0 \%$ & $21.2 \%$ & $0.2 \%$ & $4.9 \%$ & $30.0 \%$ & $64.9 \%$ & $64.9 \%$ \\
\hline$\%^{1}>35 \mathrm{~cm}$ & $0.30 \%$ & $0.00 \%$ & $0.00 \%$ & $0.00 \%$ & $0.00 \%$ & $0.00 \%$ & $0.00 \%$ & $0.00 \%$ \\
\hline
\end{tabular}

There is no interaction between the distance between the spacers and the distance between the tying points.

- The control factors (distance between spacers and distance between the tying points) are inversely proportional to the cover thickness, i.e. smaller distances result in a better achievement of the cover.

When the distance between the spacers and the tying points is controlled, the probability of achieving satisfactory cover is higher.

\section{Acknowledgements}

To Brazilian Research Funding Agencies CNPq and CAPES for their support, to the Federal University of Rio Grande do Sul (UFRGS) particularly to the NORIE facilities for their assistance and making all equipment available and to the company that allowed us to use their construction site in this study.

\section{Bibliographic references}

[1] BAROGHEL-BOUNY, V.; CAPRA, B.; LAURENS, S. A durabilidade das armaduras e do concreto de cobrimento. In: Durabilidade do Concreto: Bases científicas para a formulação de concretos duráveis de acordo com o ambiente. Ed. J. P. Ollivier e A. Vichot. Ed. Tradução: O. Cascudo e H. Carasek. São Paulo: IBRACON, 2014

[2] ROSTAM, S. Service life design of concrete structures - A challenge to designers as well as to owners. In: Asian Journal of Civil Engineering (Building and Housing). Vol. 6, No 5, 2005.

[3] LI, K.; CHEN, Z.; LIAN, H. Concepts and requirements of durability design for concrete structures: an extensive review of CCES01. In: Materials and Structures. Ed. 41. Pages 717731. Beijing, 2007.

[4] ASSOCIAÇÃO BRASILEIRA DE NORMAS TÉCNICAS. NBR 6118: Projeto de estruturas de concreto - Procedimento. Rio de Janeiro, 2014.

[5] GENTIL, V. Corrosão. 3 ed. Rio de Janeiro: LTC, 1996.

[6] MARSH, B. Specification and achievement of cover to reinforcement. In: Advanced Concrete Technology Set. Vol. 1, Pages 1-9, 2003.

[7] CLARK, L. A. SHAMMAS-TOMA, M. G. K.; SEYMOUR, D. E.; PALLETT, P. F.; MARSH, B. K. How can we get the cover we need? In: The Structure Engineer. Journal of the Institution of Structural Engineers. Volume 75, N 17. UK, 2007.
[8] SHAW, C. B. Durability of Reinforcement Concrete. 2007. Disponível em: http://www.localsurveyorsdirect.co.uk/sites/ default/files/attachments/reinforced\%20concrete.pdf. Acesso em: maio 2014.

[9] BENEDETTI, K. Sensibilidade da segurança de vigas e lajes de concreto armado a erros de execução. 2013. 198 f. - Escola de Engenharia, Universidade Federal do Rio Grande do Sul, Porto Alegre, 2013.

[10] PEREIRA, E.; RESENDE, A.; MEDEIROS M. H. F. de; MENEGHETTI, L. C. Ensaios acelerado por cloretos: efeito da sílica ativa, relação água/aglomerante e espessura de cobrimento do concreto. In: Revista Ibracon de Estruturas e Materiais, São Paulo, v. 6, n. 4, agosto 2013, p. 561-581, 2013.

[11] ASSOCIAÇÃO BRASILEIRA DE NORMAS TÉCNICAS. NBR 14931: Execução de estruturas de concreto - procedimento. Rio de Janeiro, 2004.

[12] INSTRUCCIÓN ESPAÑOLA DEL HORMIGÓN ESTRUCTURAL (EHE). EHE 08 - Capítulo XIII - Ejecución. España, 2008.

[13] COMITÉ EURO-INTERNATIONAL DU BÉTON (CEB). Bulletin d'Information No. 201 - Spacers, chairs and tying of steel reinforcement. Lausanne: Comité Euro-International du Béton, 1990

[14] BRITISH STANDARDS INSTITUTION (BSI). BS 7973: Spacers and chairs for steel reinforcement and their specification - Part 2: Fixing and application of spacers and chairs and tying of reinforcement. 2001.

[15] HELENE, P. R. do L. Cobrimento garantido. In: Revista Construção Mercado, São Paulo, Editora Pini, edição 140, março 2013.

[16] CAMPOS, D. de. Cobrimento de armadura em estruturas de concreto armado: análise comparativa entre valores antes, durante e depois da concretagem. Universidade Federal do Rio Grande do Sul. Porto Alegre, 2013.

[17] BARNES, R.; ZHENG, T. Research on factors affecting concrete cover measurements. In: The e-Journal of Nondestructive Testing. Austrália, december 2008.

[18] MENNA BARRETO, M. F. F. et al. Influência do diâmetro da armadura no cobrimento final de lajes de concreto armado. In: Congresso Brasileiro do Concreto, 56, 2014, Natal. Anais... São Paulo: IBRACON, 2014. 